\title{
Safety and Efficacy of High-flow Nasal Cannula Therapy in the Pediatric Emergency Department
}

\author{
Çocuk Acil Servisinde Yüksek Akışlı Nazal Kanül Tedavisinin Güvenilirliği ve Etkinliği
}

\author{
(D) Ali Yurtseven1, (1) Eylem Ulaş Saz1, (D) Halim Hennes² \\ 1 Ege University Faculty of Medicine, Department of Pediatrics, Division of Emergency Medicine, Izmir, Turkey \\ 2 University of Texas, Southwestern Medical Center, Department of Pediatric Emergency, Texas, USA
}

\section{Abstract}

The objective of this review was to provide a summary of the current literature on heated humidified high-flow nasal cannula therapy (HFNC), discuss the mechanism of action, describe how HFNC is used, indications for use, and safety and efficacy in the pediatric emergency department (PED). A computer-based literature search through January 2019 was conducted using MEDLINE (PubMed) and Google Scholar. We included all original studies on HFNC use in pediatric patients in the PED. Our search identified fourteen studies that met the search criteria and all were reviewed by the authors. The majority of patients $(1867,67 \%)$ included in these studies were children with acute bronchiolitis. While, most of the studies concluded that HFNC was more effective than standard oxygen therapy in reducing respiratory rate, heart rate, endotracheal intubation rate and pediatric intensive care unit (PICU) admission, the limited data suggest that HFNC had similar effect to continuous positive airway pressure in patients with acute bronchiolitis. There is no general practice about the initiation and weaning of HFNC yet. Although a small number of adverse effects have been reported, HFNC therapy was usually safe. HFNC is a useful treatment modality for children with acute bronchiolitis. In the acute setting, it was shown to decrease respiratory rate, heart rate, RS, need for endotracheal intubation, and PICU admission. However, there is limited data on the initiation process, flow rate, and standardized protocol for weaning patients off HFNC. Further studies are needed to address these issues.

Keywords: Child, emergency department, oxygenation, heated humidifier, humidification, high flow gas

\section{Öz}

Bu derlemenin amacı, çocuk acil serviste (ÇAS) kullanılan ısıtılmış nemlendirilmiş yüksek akımlı nazal kanül oksijen (YANKO) tedavisi ile ilgili literatürün gözden geçirilmesi ve bu tedavinin etki mekanizmasının, kullanım endikasyonlarının, etkinliğinin ve güvenilirliğinin tartışımasıdır. MEDLINE (PubMed) ve Google Scholar kullanılarak Ocak 2019'a kadar olan tüm yayınlar tarandı. ÇAS'de gerçekleştirilen YANKO kullanımı ile ilgili tüm orijinal çalışmalar derlemeye dahil edildi. Arama kriterlerini karşılayan literatürdeki on dört çalışma incelendi. Bu çalışmalara dahil edilen hastaların çoğu (1867, \%67) akut bronşiyolitli çocuklardı. Çalışmaların çoğu, YANKO'nun solunum hızı, kalp atım hızı, endotrakeal entübasyon ve yoğun bakım (YB) yatış oranını azaltmada standart oksijen tedavisinden daha etkili olduğunu belirtmekle birlikte, bazı çalışmalar bu tedavinin akut bronşiyolitli hastalarda en az diğer non-invaziv ventilasyon yöntemleri kadar etkili olduğunu göstermiştir. YANKO tedavisinin başlatılması ve kesilmesi konusunda henüz bir görüş birliği olmamakla birlikte, bu yöntemin güvenle kullanılabileceği belirtilmektedir. YANKO tedavisi, özellikle akut bronşiyoliti olan çocuklar için kullanışlı bir tedavi yöntemidir. Acil serviste solunum sıkıntısı nedeniyle tedavi edilen çocuklarda solunum sıkıntısını, endotrakeal entübasyon ve YB yatış oranını azalttığı gösterilmiştir. Bununla birlikte, başlangıç süreci, akış hızı ve hastaları tedaviden ayırma ile ilgili sınırlı veri vardır. Bu konuların ele alınacağı daha fazla çalışmaya ihtiyaç vardır.

Anahtar Kelimeler: Çocuk, acil servis, oksijenizasyon, ısıtılma, nemlendirme, yüksek akışlı oksijen 


\section{Introduction}

Respiratory distress is one of the most common and most important complaints in children presenting to the pediatric emergency department (PED). ${ }^{1}$ Viral bronchiolitis, a common seasonal illness causing respiratory distress in children, leads to over 300.000 PED visits annually in the USA. 2,3 As such, the management of acute respiratory distress has evolved over the past four decades. Whereas supplemental oxygen has been the mainstay for managing respiratory distress in children with bronchiolitis, many other treatments such as albuterol, epinephrine, and systemic corticosteroids, nebulized hypertonic saline, heliox have been investigated. ${ }^{4}$ While supplemental oxygen is provided via mask or nasal cannula for children with mild or moderate respiratory distress, non-invasive or invasive ventilation support is often required for severe cases. In recent years, high-flow nasal cannula (HFNC), a non-invasive ventilation (NIV) modality, has become the preferred initial treatment method for children with respiratory distress. ${ }^{5}$ The use of HFNC was previously limited to in neonatal intensive care units and pediatric intensive care units (PICU). ${ }^{6}$ Given its proven safety and efficacy, it is currently used with increasing frequency in PEDs and general pediatric wards. ${ }^{7}$ HFNC delivers heated and humidified high flow (>2 L/min) oxygen that maintains positive airway pressure. The heated humidified air/oxygen mixture does not irritate the respiratory mucosa. ${ }^{8}$ HFNC provides ventilation in anatomical dead space and decreases upper airway resistance. Thus, it facilitates the excretion of carbon dioxide $\left(\mathrm{CO}_{2}\right)$ and supports ventilation perfusion balance. ${ }^{9,10}$

Current literature has shown that HFNC decreased the need for endotracheal intubation and PICU admission rates in children with bronchiolitis. ${ }^{11}$ Furthermore, it has been reported that HFNC was as effective as other non-invasive ventilatory support modalities in these patients. ${ }^{12}$ To date, there are no clear guidelines on when to initiate HFNC, which air/oxygen flow rate is effective, how and when to wean patients off the HFNC system, or its use in the PED setting. ${ }^{13-15}$

The objective of our review was to provide a summary of the current HFNC literature, discuss the mechanism of action, describe how HFNC is used, indications for use, safety, and efficacy.

\section{Methods-Literature Search}

We conducted a systematic literature search of the databases MEDLINE (PubMed) and Google Scholar up to January 2019. We first searched for all articles with the keywords high flow nasal cannula or HFNC and articles including children 0-18 years of age. Then, we limited the search to articles conducted in emergency department, and to English and Turkish language studies in human.

All original publications on children with respiratory distress who received HFNC in the PED were included. Studies completed on hospitalised children were excluded.

\section{Study Characteristics}

A total of 120 relevant records were retrieved with reference to our search criteria. After duplicates and irrelevant studies were removed, 64 studies were further scrutinized. Of these, 14 publications on children treated with HFNC in the PED were identified. Study design, outcome and key results are summarized in Table 1. Seven studies included only children with bronchiolitis ${ }^{16-22}$, six studies had children with respiratory distress due to any disease $\mathrm{e}^{23-28}$ and one study was on children with acute asthma exacerbations. ${ }^{29}$ Five studies enrolled children up to 24 months of age 19,20,22,24,27, four enrolled children up to 18 years of age $\mathrm{e}^{23,25,26,28}$, four included children up to 12 months of age only $16-18,21$, and one enrolled children aged 1 to 14 years. ${ }^{29}$

In five studies, HFNC devices were used with $2 \mathrm{~L} / \mathrm{kg} / \mathrm{min}$ flow rate for infants or children up to $10 \mathrm{~kg}^{17,21,25,28,29}$, five studies did not report a specific flow rate ${ }^{18,20,24,26,27}$, in one study, $1 \mathrm{~L} /$ $\mathrm{kg} / \mathrm{min}$ flow rate was utilized ${ }^{19}$ and in one study, both $1 \mathrm{~L} / \mathrm{kg} /$ min flow rate and $2 \mathrm{~L} / \mathrm{kg} / \mathrm{min}$ were used. ${ }^{22} \mathrm{In}$ another study a flow rate of $1-8 \mathrm{~L} /$ min was used $^{16}$, and in the last study a flow rate of 4-10 L/min was used for children younger than 24 months of age and 5-50 L/min flow rates in older children. ${ }^{23}$

Four studies compared HFNC to standard oxygen therapy ${ }^{18,19,21,29}$, three evaluated reasons for HFNC therapy failure $24,25,28$, and two studies evaluated the effects of HFNC on intubation and PICU admission rates. ${ }^{17,23}$ While two studies tried to determine the safety and efficacy of HFNC therapy ${ }^{20,26}$, one study compared $1 \mathrm{~L} / \mathrm{kg} / \mathrm{min}$ flow rate with $2 \mathrm{~L} / \mathrm{kg} / \mathrm{min}^{22}$, one study compared HFNC to continuous positive airway pressure (CPAP $)^{27}$, and another one measured nasopharyngeal pressures at varying flow rates. ${ }^{16}$

\section{Basic Components of HFNC System}

HFNC, a closed system, generally comprises a flow oxygen/ air blender which regulates the pressurized oxygen and air; a water reservoir that is interdependent to an heater and humidifier; a heater and humidifier; an insulated heated circuit that checks and protects the temperature and relative humidity of the conditioned gas delivered to the patient; and a special nasal cannula (Figure 1). ${ }^{10}$

HFNC system heats the gas to near the body temperature up to $37^{\circ} \mathrm{C}$, humidifies and delivers to the patient via nasal 
cannula. Although, currently a couple of HFNC circuits and devices are produced by different manufacturers, they have same basic action mechanisms.?

\section{Mechanism of Action}

HFNC is defined as heated and humidified mixture of air and oxygen administered via nasal cannula at a higher flow ( $>2 \mathrm{~L} / \mathrm{min}$ ) than the patient's inspiratory flow. ${ }^{8}$ It is adopted that flow rates $>6 \mathrm{~L} / \mathrm{min}$ are high flow in children. ${ }^{11}$ Some researchers regulate the flow rates according to body weight and while some of them recommend using $1 \mathrm{~L} / \mathrm{kg} / \mathrm{min}$, others suggested $2 \mathrm{~L} / \mathrm{kg} / \mathrm{min}$. ${ }^{17,19,30}$ The flow rate is also chosen by age in some centers. ${ }^{31}$ There has been no consensus about this issue yet. ${ }^{14}$ Whichever flow rate is selected, HFNC has several advantages over conventional "low-flow" oxygen therapy in washout of nasopharyngeal dead space, gas exchange, oxygenation, decrease of inspiratory resistance and work of breathing, improvement of airway conductance and mucociliary clearance, reduction of the metabolic cost and providing an end-distending pressure to the lungs. ${ }^{32}$

The air in the nasopharynx and trachea includes high proportion of $\mathrm{CO}_{2}$ at the end of exhalation during normal breathing. This air is changed with the fresh air on the next respiratory cycle that decreases the efficiency of gas exchange. But, in patients receiving HFNC therapy, the oxygen-rich fresh gas rapidly covers the nasal cavity, pharynx, and trachea, and $\mathrm{CO}_{2}$-rich gas is washed out from the dead spaces, thus improves alveolar

Table 1. Overview of the 14 original studies including children receiving HFNC in the ED

\begin{tabular}{|c|c|c|c|c|}
\hline $\begin{array}{l}\text { Authors } \\
\text { Year } \\
\text { Type of study }\end{array}$ & $\begin{array}{l}\text { Study group } \\
\text { Sample size and treatment } \\
\text { Age of patients }\end{array}$ & Flow rate & Main outcomes & Main findings \\
\hline $\begin{array}{l}\text { Arora et al. }{ }^{16} \\
2012 \\
\text { Prospective } \\
\text { observational }\end{array}$ & $\begin{array}{l}\text { Infants with bronchiolitis } 25 \text { (all } \\
\text { cases received } \text { HFNC }^{\star} \text { ) } \\
\text { Age }<12 \text { months }\end{array}$ & $1-8 \mathrm{~L} / \mathrm{min}$ & $\begin{array}{l}\text { NP ₹pressures at varying } \\
\text { flow rates of HFNC }\end{array}$ & $\begin{array}{l}\text { Increasing flow rate of HFNC up to } 8 \mathrm{~L} / \mathrm{min} \\
\text { were associated with linear increase in NP } \\
\text { pressure }\end{array}$ \\
\hline $\begin{array}{l}\text { Wing et al. } \\
2012 \\
\text { Retrospective } \\
\text { observational case } \\
\text { control }\end{array}$ & $\begin{array}{l}42 \% \text { had asthma } \\
24 \% \text { had bronchiolitis } \\
19 \% \text { had pneumonia } \\
15 \% \text { had other illnes } \\
848 \text { ( } 228 \text { cases received HFNC) } \\
\text { Age } 0-18 \text { years }\end{array}$ & $\begin{array}{l}2-10 \mathrm{~L} / \mathrm{min} \\
\text { for pre-adolescent, } \\
5-50 \mathrm{~L} / \mathrm{min} \\
\text { for adolescents }\end{array}$ & $\begin{array}{l}\text { The rate of intubation } \\
\text { and median PICUT LOS } \neq \\
\text { with and without using } \\
\text { HFNC }\end{array}$ & $\begin{array}{l}\text { Using HFNC decreased } \\
50 \% \text { the need of intubation but didn't } \\
\text { significant influence in mortalite and median } \\
\text { PICU LOS }\end{array}$ \\
\hline $\begin{array}{l}\text { Kelly et al. }{ }^{24} \\
2013 \\
\text { Retrospective } \\
\text { observational }\end{array}$ & $\begin{array}{l}46 \% \text { had bronchiolitis } \\
28 \% \text { had pneumonia } \\
26 \% \text { had other illnes } \\
498 \text { (all cases received HFNC) } \\
\text { Age }<2 \text { years }\end{array}$ & Not given & $\begin{array}{l}\text { Patient characteristics } \\
\text { that predict success or } \\
\text { failure of HFNC }\end{array}$ & $\begin{array}{l}\mathrm{RR}^{\#} \text { greater than } 90^{\text {th }} \text { percentile for } \\
\text { age, initial venous } \mathrm{PaCO}_{2}^{\#} \text { greater than } \\
50 \mathrm{mmHg} \text {, or } \mathrm{pH} \text { less than } 7.30 \text { were } \\
\text { associated with failure of HFNC therapy. } \\
\text { A diagnosis of acute bronchiolitis was } \\
\text { protective with respect to intubation } \\
\text { following HFNC }\end{array}$ \\
\hline $\begin{array}{l}\text { Long et al. }{ }^{25} \\
2016 \\
\text { Prospective } \\
\text { observational }\end{array}$ & $\begin{array}{l}69 \% \text { had bronchiolitis } \\
24 \% \text { had pneumonia } \\
7 \% \text { had other illnes } \\
71 \text { (all cases received HFNC) } \\
\text { Age 3-20 months }\end{array}$ & $\begin{array}{l}2 \mathrm{~L} / \mathrm{kg} / \mathrm{min} \text { for the } \\
\text { first } 10 \mathrm{~kg} \text {, then } \\
0.5 \mathrm{~L} / \mathrm{kg} / \mathrm{min} \\
\text { thereafter }\end{array}$ & $\begin{array}{l}\text { Evaluating HFNC use, } \\
\text { failure rates, predictors } \\
\text { of failure and adverse } \\
\text { events }\end{array}$ & $\begin{array}{l}\text { The therapy failure was } 39 \% \text {. Initial mean } \\
\text { RR and } \mathrm{HR}^{8} \text { were higher in the non- } \\
\text { responders group. One patient with asthma } \\
\text { developed air leak syndrome }\end{array}$ \\
\hline $\begin{array}{l}\text { Milani et al. } \\
2016 \\
\text { Prospective } \\
\text { observational }\end{array}$ & $\begin{array}{l}\text { Infants with bronchiolitis } \\
36 \text { ( } 18 \text { cases received HFNC, } 18 \\
\text { cases were treated with low-flow } \\
\text { oxygen) } \\
\text { Age }<12 \text { months }\end{array}$ & $\begin{array}{l}\mathrm{L} / \min =8 \mathrm{~mL} / \mathrm{kg} \times \\
\mathrm{RR} \times 0.3\end{array}$ & $\begin{array}{l}\text { Comparing the RR, } \\
\text { respiratory effort, } \\
\text { ability to feed, LOS, } \\
\text { the duration of oxygen } \\
\text { supplementation in the } \\
\text { two groups }\end{array}$ & $\begin{array}{l}\text { Improvements in the RR, respiratory effort } \\
\text { and ability to feed were significantly faster } \\
\text { in the HFNC group than the low-flow oxygen } \\
\text { group. The HFNC group needed oxygen for } \\
2 \text { days less and LOS was } 3 \text { days shorter than } \\
\text { in the low flow oxygen group }\end{array}$ \\
\hline
\end{tabular}




\section{Table 1. Overview of the $\mathbf{1 3}$ original studies including children receiving HFNC in the ED (continued)}

\begin{tabular}{|c|c|c|c|c|}
\hline $\begin{array}{l}\text { Kepreotes et al. }{ }^{18} \\
2017 \\
\text { Randomised controlled }\end{array}$ & $\begin{array}{l}\text { Infants with bronchiolitis } \\
202 \text { ( } 101 \text { cases received HFNC, } \\
101 \text { cases were treated with } \\
\text { low-flow oxygen) } \\
\text { Age }<24 \text { months }\end{array}$ & $1 \mathrm{~L} / \mathrm{kg} / \mathrm{min}$ & $\begin{array}{l}\text { Comparing HFNC with standard } \\
\text { low-flow nasal in time to } \\
\text { weaning off oxygen, treatment } \\
\text { failure and serious adverse } \\
\text { events, }\end{array}$ & $\begin{array}{l}\text { Time to weaning off oxygen did not } \\
\text { differ significantly between two groups. } \\
\text { The therapy failure was higher in the } \\
\text { standard therapy group. No serious } \\
\text { oxygen-related adverse events }\end{array}$ \\
\hline $\begin{array}{l}\text { Davison et al. }{ }^{19} \\
2017 \\
\text { Retrospective } \\
\text { observational }\end{array}$ & $\begin{array}{l}\text { Infants with bronchiolitis } \\
61 \text { (all cases received HFNC) } \\
\text { Age }<24 \text { months }\end{array}$ & $\begin{array}{l}0.6 \text { to } 3.3 \\
\mathrm{~L} / \mathrm{kg} / \mathrm{min}\end{array}$ & $\begin{array}{l}\text { Improving in some physiological } \\
\text { parameters (HR, RR, WOB }) \\
\text { and evaluating adverse events }\end{array}$ & $\begin{array}{l}\text { The WOB, RR and HR reduced with } \\
\text { using HFNC. No adverse events related } \\
\text { to HFNC therapy }\end{array}$ \\
\hline $\begin{array}{l}\text { Vitaliti et al. }{ }^{25} \\
2017 \\
\text { Randomised controlled }\end{array}$ & $\begin{array}{l}77.5 \% \text { had bronchiolitis } \\
17.5 \% \text { had pneumonia } \\
5 \% \text { had asthma } \\
60 \text { ( } 20 \text { cases received HFNC, } \\
20 \text { cases were treated with } \\
\text { CPAPU, } 20 \text { cases were treated } \\
\text { with standard pharmacological } \\
\text { treatment) } \\
\text { Age } 1-24 \text { months }\end{array}$ & $1-3 \mathrm{~L} / \mathrm{kg} / \mathrm{min}$ & $\begin{array}{l}\text { Evaluating efficacy }\left(\mathrm{RR}, \mathrm{SpO}_{2},\right. \\
\mathrm{pH}, \mathrm{PaCO}_{2}, \mathrm{PaO}_{2} \mathrm{p} \text { and } \mathrm{PaO}_{2} / \\
\left.\mathrm{FiO}_{2}\right) \text { and safety of HFNC } \\
\text { and CPAP. Comparing the } 2 \\
\text { NIV methods with standard } \\
\text { pharmacological treatment }\end{array}$ & $\begin{array}{l}\text { Both CPAP and HFNC were efficient } \\
\text { in improving the clinical parameters, } \\
\text { however CPAP was more effective } \\
\text { than HFNC. CPAP had a better clinical } \\
\text { course in LOS and in use of medication } \\
\text { compared with HFNC and standard } \\
\text { treatment }\end{array}$ \\
\hline $\begin{array}{l}\text { Franklin et al. }{ }^{20} \\
2018 \\
\text { Multicenter } \\
\text { randomised controlled }\end{array}$ & $\begin{array}{l}\text { Infants with bronchiolitis } 1472 \\
\text { ( } 739 \text { cases received HFNC, } 733 \\
\text { cases treated with standard } \\
\text { oxygen) } \\
\text { Age }<12 \text { months }\end{array}$ & $\begin{array}{l}2 \mathrm{~L} / \mathrm{kg} / \mathrm{min} \\
\operatorname{Max} \\
25 \mathrm{~L} / \mathrm{min}\end{array}$ & $\begin{array}{l}\text { Comparing HFNC with standard } \\
\text { low-flow nasal oxygen in terms } \\
\text { of treatment failure, LOS, } \\
\text { duration of oxygen therapy, } \\
\text { intubation PICU admission and } \\
\text { adverse events }\end{array}$ & $\begin{array}{l}\text { HFNC therapy had significantly } \\
\text { lower rate of treatment failure than } \\
\text { standard oxygen therapy. No significant } \\
\text { differences were observed in the LOS, } \\
\text { the duration of oxygen therapy, the } \\
\text { intubation and the PICU admission. } \\
\text { One patient from each group occured } \\
\text { pneumothorax }\end{array}$ \\
\hline $\begin{array}{l}\text { Er et al. }^{26} \\
2018 \\
\text { Retrospective } \\
\text { observational }\end{array}$ & $\begin{array}{l}60 \% \text { had pneumonia } \\
40 \% \text { had bronchiolitis } \\
154 \text { (all cases received HFNC) } \\
\text { Age } 5-23 \text { months }\end{array}$ & $\begin{array}{l}2 \mathrm{~L} / \mathrm{kg} / \mathrm{min} \text { for } \\
\text { infants and } 1 \mathrm{~L} / \\
\mathrm{kg} / \mathrm{min} \text { for older } \\
\text { children } \\
\text { Max } 25 \mathrm{~L} / \mathrm{min}\end{array}$ & $\begin{array}{l}\text { Assessing early determining } \\
\text { factors of unresponsiveness to } \\
\text { HFNC therapy }\end{array}$ & $\begin{array}{l}\text { On admission, lower } \mathrm{SpO}_{2}, \mathrm{SpO}_{2} / \mathrm{FiO}_{2} \\
\text { ratio, venous } \mathrm{pH} \text {, and higher } \mathrm{pCO}_{2} \text { were } \\
\text { related with unresponsiveness. Also the } \\
\text { reduction of } \mathrm{RR} \text {, respiratory score, and } \\
\mathrm{SpO}_{2} / \mathrm{FiO}_{2} \text { ratio at the first hour was } \\
\text { greater in the responsive group }\end{array}$ \\
\hline $\begin{array}{l}\text { Ballestero et al. }{ }^{17} \\
2018 \\
\text { Prospective } \\
\text { randomised }\end{array}$ & $\begin{array}{l}\text { Patients with asthma } \\
62 \text { ( } 30 \text { cases received HFNC, } \\
32 \text { cases treated with standard } \\
\text { oxygen) } \\
\text { Age } 1-14 \text { years }\end{array}$ & $\begin{array}{l}2 \mathrm{~L} / \mathrm{kg} / \mathrm{min} \text { for the } \\
\text { first } 10 \mathrm{~kg} \text {, then } \\
0.5 \mathrm{~L} / \mathrm{kg} / \mathrm{min} \\
\text { thereafter } \\
\text { Max } 60 \mathrm{~L} / \mathrm{min}\end{array}$ & $\begin{array}{l}\text { Comparing HFNC with } \\
\text { conventional oxygen therapy in } \\
\text { the respiratory score, hospital } \\
\text { discharge, LOS, need for } \\
\text { additional therapies and side } \\
\text { effects }\end{array}$ & $\begin{array}{l}\text { HFNC was superior than conventional } \\
\text { oxygen therapy for reducing respiratory } \\
\text { distress within the first } 2 \text { hours. There } \\
\text { were no significant differences in } \\
\text { hospital discharge, LOS and need for } \\
\text { additional therapies. No side effects } \\
\text { occurred }\end{array}$ \\
\hline $\begin{array}{l}\text { Yurtseven et al. }{ }^{22} \\
2019 \\
\text { Prospective } \\
\text { observational }\end{array}$ & $\begin{array}{l}\text { Infants with bronchiolitis } \\
168 \text { ( } 88 \text { cases received } 1-\mathrm{L} / \mathrm{kg} / \\
\text { min HFNC flow rate and } 80 \\
\text { cases } 2-\mathrm{L} / \mathrm{kg} / \mathrm{min} \text { ) } \\
\text { Age }<24 \text { months }\end{array}$ & $\begin{array}{l}\text { One group } 2 \mathrm{~L} / \mathrm{kg} / \\
\text { min and } \\
\text { other group } \\
1 \mathrm{~L} / \mathrm{kg} / \min \\
\text { Max } 25 \mathrm{~L} / \min \end{array}$ & $\begin{array}{l}\text { Comparing the } \mathrm{HFNC} \text { flow rate } \\
\text { of } 1 \mathrm{~L} / \mathrm{kg} / \mathrm{min}(1 \mathrm{~L}) \text { with } \\
2 \mathrm{~L} / \mathrm{kg} / \mathrm{min}(2 \mathrm{~L}) \text { in patients } \\
\text { with severe bronchiolitis } \\
\text { presenting to the pediatric } \\
\text { emergency department }\end{array}$ & $\begin{array}{l}\text { HFNC therapy with a } 2 \mathrm{~L} / \mathrm{kg} / \mathrm{min} \text { flow } \\
\text { rate was not clinically more effective } \\
\text { than } 1 \mathrm{~L} / \mathrm{kg} / \mathrm{min} \text { in patients with severe } \\
\text { bronchiolitis. } 1 \mathrm{~L} / \mathrm{kg} / \text { min ensured earlier } \\
\text { impact and was well tolerated }\end{array}$ \\
\hline
\end{tabular}

ventilation and reduces the effects of rebreathing. ${ }^{33}$ It is stated that this mechanism is especially important in small children, since they have higher extrathoracic anatomical dead space. ${ }^{34}$ In a study using computational fluid dynamics simulations of the $\mathrm{CO}_{2}$ concentration within the upper airway model in a patient receiving HFNC, a nasopharyngeal washout phenomenon was observed and the amount of $\mathrm{CO}_{2}$ cleared from the nasal cavity was found to increase in a flow-dependent manner over the range of flows simulated. ${ }^{35}$ Another study utilizing neonatal piglets with lung injury has also indicated that HFNC could serve as a means of oxygenation support independent of supplemental oxygen administration by way of nasopharyngeal dead space elimination. ${ }^{36}$
The nostrils and the nasal passages have a large surface area and cause high resistance in the human airway. ${ }^{37}$ HFNC delivers a flow that is equal to or exceeding the patient's peak inspiratory pressure via an appropriately placed nasal cannula, there by bypassing this area that has the highest resistance in the respiratory tract and preventing nasopharyngeal collapse which normally happens during spontaneous breathing. ${ }^{38}$ Heated humidified gas also reduces airway resistance, increases mucus clearance and prevents atelectasis through improving mucociliary function. ${ }^{39}$ These effects of HFNC can also play a role in decreasing the inspiratory resistance.

The respiratory muscles work hard in children with severe respiratory distress and increase energy consumption. If 
this condition persists for a long time, respiratory muscle insufficiency may occur and intubation may be required. HFNC provides heated oxygen-rich gas, thereby the energy cost of heating the inspired gas to body temperature disappears, achieving more energy and preventing respiratory muscles failure. $^{33}$

Creating positive end expiratory pressure (PEEP) is one of the most important mechanisms of action of HFNC and especially with this effect, it is accepted as a NIV modality. ${ }^{33,38}$ Several studies have shown that HFNC ensure PEEP in both children and adults. ${ }^{32}$ Particularly, PEEP in closed-mouth state has been reported to be markedly higher than in open-mouthed state. ${ }^{16}$ In their study including 21 infants with acute respiratory syncytial virus bronchiolitis, Milesi et al. ${ }^{40}$, found that only flows $\geq 6 \mathrm{~L} /$ min provided positive pharyngeal pressure throughout the respiratory cycle. PEEP can also prevent atelectasis and help lung recruitment, thus improve ventilation-perfusion stability, alveolar ventilation and oxygenation.

\section{Initiation and Weaning}

If we consider using HFNC therapy for any patient, we need to set up basically 2 variables: $\mathrm{FiO}_{2}$, and flow rate. Another variable, the gas temperature, is usually kept constant about $1-2^{\circ} \mathrm{C}$ below body temperature. $\mathrm{FiO}_{2}$ is adjusted at 0.4 initially and can rise to 0.5-0.6 provided oxygen saturation $\left(\mathrm{SpO}_{2}\right)$ is $>92 \%$. In follow-up, $\mathrm{FiO}_{2}$ is arranged up or down to achieve

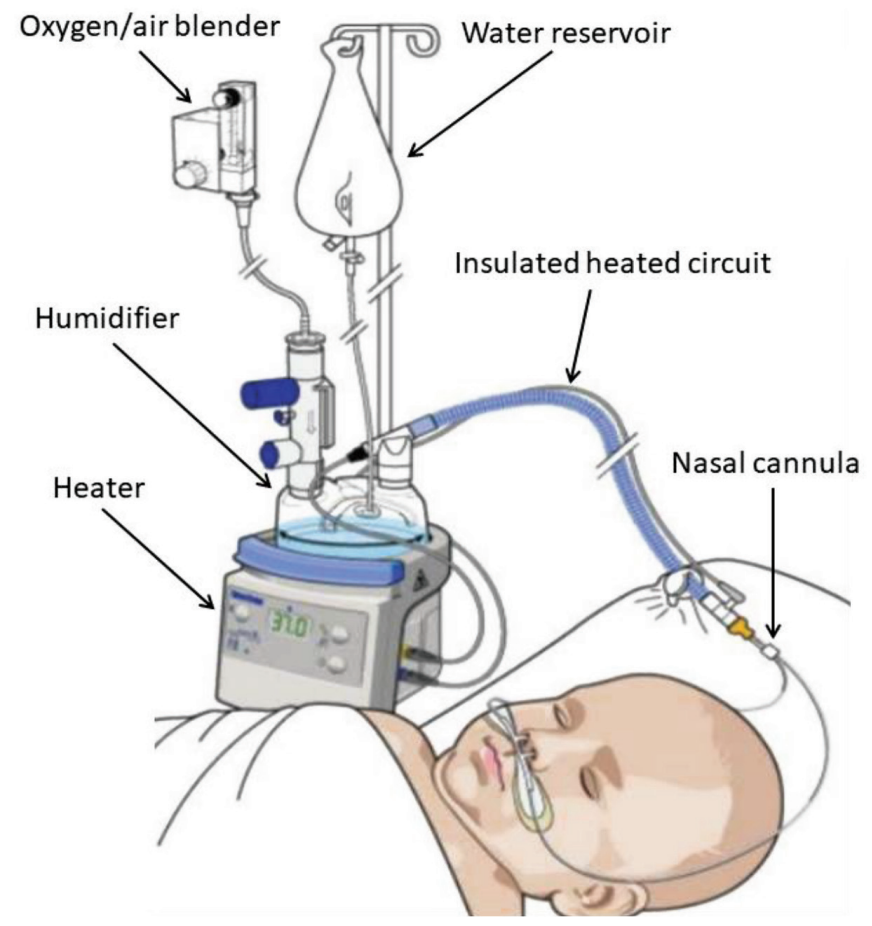

Figure 1. Components of the HFNC system: A oxygen/air blender, water reservoir, humidifier, heater, insulated heated circuit, and nasal cannula HFNC: High-flow nasal cannula the target $\mathrm{SpO}_{2}$, typically $92 \%-97 \%{ }^{7}$ While there is no general acceptance about optimal initial HFNC flow rate, HFNC therapy is usually started with $4-6 \mathrm{~L} / \mathrm{min}$ flow rate or more in non-newborn children. ${ }^{41}$ The studies have generally suggested two types of HFNC flow rate preference; age-based protocol and weight-based protocol. ${ }^{30,31}$ Hutchings et al. ${ }^{42}$, who have reported one of the best age-based protocols of HFNC flow rate, have recommended $6 \mathrm{~L} / \mathrm{min}$ for patients up to 1 month, $8 \mathrm{~L} / \mathrm{min}$ for $1-12$ months, $10 \mathrm{~L} / \mathrm{min}$ for $1-4$ years and $12 \mathrm{~L} / \mathrm{min}$ for 5 years and over. Other age-based studies have advised $2 \mathrm{~L} / \mathrm{min}$ for patients $<6$ months, $4 \mathrm{~L} / \mathrm{min}$ for $6-18$ months and $8 \mathrm{~L} / \mathrm{min}$ for those aged 18-24 months; or 8-12 L/min for infants and 20-30 L/min for children. ${ }^{31,41}$ Studies, which have suggested the HFNC flow rate to be according to weight, have mostly proposed flows such as $1 \mathrm{~L} / \mathrm{kg} / \mathrm{min}$ or $2 \mathrm{~L} / \mathrm{kg} /$ $\min { }^{17,19,21}$ Although, some physiological studies reported that a flow rate $\geq 2 \mathrm{~L} / \mathrm{kg} / \mathrm{min}$ was required to achieve optimal effects, clinical studies have not supported this data. ${ }^{15,22,38,40}$ Moreover, it has been indicated that a flow $\geq 2 \mathrm{~L} / \mathrm{kg} / \mathrm{min}$ was associated with a higher rate of discomfort and with a longer stay in the PICU. ${ }^{15}$ In other age-based studies; while Long et al. ${ }^{25}$ have used $2 \mathrm{~L} / \mathrm{kg} / \mathrm{min}$ HFNC flow rate for the first $10 \mathrm{~kg}$, then $0.5 \mathrm{~L} / \mathrm{kg} / \mathrm{min}$ for every kilogram thereafter, Er et al. ${ }^{28}$ have chosen $2 \mathrm{~L} / \mathrm{kg} / \mathrm{min}$ for infants and $1 \mathrm{~L} / \mathrm{kg} / \mathrm{min}$ for older children. According to our experience, HFNC therapy can be started with $6 \mathrm{~L} / \mathrm{min}$ and adjusted up to $10 \mathrm{~L} / \mathrm{min}$ for children with bronchiolitis.

Weaning is another uncertainty in the HFNC therapy. Few suggestions are available about it. Betters et al. ${ }^{43}$, who have reported one of the most detailed weaning protocol, created a respiratory assessment score (RAS) based on six components [respiratory rate $(R R)$, chest movement, intercostal retractions, xiphoid retractions, nasal flaring, and expiratory grunt], and scored each category 0,1 , or 2 , for up to a total of 12 points. They assessed their patients for RAS every 12 hours. Patients, who have 6 or lower RAS, were weaned and started low-flow nasal cannula settings. Patients with a RAS of 7 or 8 had HFNC flow reduced by half, and patients scoring more than 8 were maintained on initial settings and evaluated during the next 12-hour shift. Although, this protocol could be appropriate in $\mathrm{PICU}$, it may not be useful for $E D$, since patients are evaluated at long intervals. Hutchings et al. ${ }^{42}$ suggested another HFNC weaning protocol that based on only their local guidelines. According to their approach, $\mathrm{FiO}_{2}$ should be initially weaned to 0.4 before reducing flow rates by $0.5 \mathrm{~L} / \mathrm{min} / \mathrm{h}$ for neonates and $1 \mathrm{~L} / \mathrm{min} / \mathrm{h}$ for all other children provided the respiratory score remains under the initial trigger level. HFNC therapy is ceased when the flow rate reaches a value that is below than the initial oxygen saturations over $92 \%$ and a $\mathrm{FiO}_{2}$ of 0.4 or less. This protocol could be more useful in EDs. 


\section{Oral Feeding in Patients Receiving HFNC}

Children with respiratory distress usually present to the ED with insufficient oral intake that may increase the patient's agitation and exacerbate respiratory distress. This issue is more common particularly in infants. That is why, feeding is vital for patients on HFNC. However, no guidelines are available about enteral nutrition in children on HFNC. In a prospective, observational cohort study, Sochet et al. ${ }^{44}$ observed that in full-term children with bronchiolitis without chronic medical conditions, enteral nutrition was well tolerated during all their HFNC flow rates and respiratory rates, and the delaying nutrition was related with a longer length of hospital stay. Slain et al.$^{45}$ also found similar results and showed that children receiving HFNC therapy, who received early enteral nutrition, had a shorter PICU length of stay and lower hospital charges, and in these patients feeding-related adverse events were rare. According to the studies and our practice, enteral nutrition and especially breastfeeding should not be withheld in this population as much as possible.

\section{Clinical Effects}

The first expectation from HFNC therapy is that it improves ventilation and oxygenation. Many studies have reported that HFNC provides a decline in RR and heart rate (HR) and improvement of $\mathrm{SpO}_{2}$ and blood gas parameters. ${ }^{41,46,47}$ In a prospective randomized study conducted on children with respiratory distress (age 1-24 months) in the ED, it has been reported that $\mathrm{HFNC}$ was efficient in improving $\mathrm{SpO}_{2}$, arterial blood gas $\mathrm{PaO}_{2}$, and $\mathrm{PaO}_{2} / \mathrm{FlO}_{2}$ significantly. ${ }^{27}$ In other studies, it has been found that there was a significant reduction in $R R$ and HR with HFNC therapy. ${ }^{20,22}$

HFNC treatment achieved wide popularity especially with reports showing to reduce the rate of intubation and PICU admission. Most previous studies reported that the overall rate of intubation and PICU admission declined in patients with bronchiolitis by HFNC therapy. 48.50 In a study conducted with nearly 850 children in the ED, Wing et al. ${ }^{23}$, have showed that there was an $83 \%$ reduction in the odds of intubation in patients receiving HFNC compared with patients could not get HFNC. However, in a unique, multicenter, randomized controlled trial (RCT), comparing HFNC with standard oxygen therapy, Franklin et al. ${ }^{21}$, have found no difference in intubation rate between two groups. Mayfield et al. ${ }^{17}$, in a prospective pilot study conducted with 61 infants aged $<12$ months with bronchiolitis in the $E D$, have determined that children receiving HFNC therapy were four times less likely to need PICU admission than those receiving standard treatment. In another RCT including children with moderate bronchiolitis in the ED and comparing HFNC with standard therapy, Kepreotes et al. ${ }^{19}$ have stated that, $61 \%$ of children who experienced treatment failure on standard therapy were rescued with high-flow heated humidified oxygen. ${ }^{19}$

\section{Potential Side Effects and Safety}

Although it is accepted that HFNC treatment is generally safe, some complications have been reported. Hegde and Prodhan ${ }^{51}$ have presented 3 patients who had serious air leak syndrome complicating HFNC therapy in a case series which is still the most important publication on this subject. Additionally, in 12 clinical studies which were conducted in the ED, 2180 patients receiving HFNC were examined and totally $4(0.18 \%)$ (3 pneumothoraces and 1 superficial burn) complications were detected. ${ }^{16-29}$ Air leak syndrome has been reported in 6 patients after HFNC therapy. Of these 6 patients; two were infants with bronchiolitis, two had pneumonia (one a 16-year-old child, other one infant), one a 4-year-old child treated for asthma and the last one a 22-month-old boy was postextubation. However, all these patients had potential risks for air leak syndrome due to severe respiratory distress. Actually we do not know exactly whether they developed air leak syndrome before HFNC treatment. The findings of Franklin et al. ${ }^{21}$ study, in which they compared HFNC therapy with standard oxygen therapy, support this suspicion. In this study, they evaluated 1472 patients (739 patients in HFNC group and 733 in standard-therapy group) and found that one case of pneumothorax occurred in HFNC group and one in standard-therapy group.

Abdominal distension can sometimes be seen in children on HFNC therapy and the therapy is discontinued because of that. ${ }^{47,52}$ In a prospective observational study including 71 children aged 0-18 years receiving HFNC in ED, Long et al..$^{25}$ have reported that three patients developed abdominal distension. ${ }^{25}$

Infection development is also possible with HFNC therapy. Jhung et al. ${ }^{53}$ have reported an outbreak of Ralstonia mannitolilytica related with use of a contaminated oxygen delivery device (Vapotherm 2000i) in the US in 2005. The device was modified by the producer right after. Since that time no further infectious complications have been reported.

Other mild complications, such as mucosal injury, epistaxis, and skin irritation, may also occur with HFNC therapy, but these complications are more common with CPAP therapy. ${ }^{54}$ ten Brink et al..$^{52}$ conducted a prospective observational study with 72 children receiving HFNC in PICU and found that mucosal injury occurred in only one of them. 


\section{The Predictors of Unresponsiveness to HFNC}

Treatment failure can be expected more frequently in patients receiving HFNC with more severe respiratory distress. ${ }^{24,25,55}$ Although Wraight and Ganu ${ }^{56}$ have found that heart disease was associated with a higher failure rate, they have reached this data with only 4 patients. Therefore, this result was not reliable. In a large study conducted with children younger than 2 years in the ED, it was reported that patients who were non-responders to HFNC therapy had a respiratory rate higher than the $90^{\text {th }}$ percentile for age, an initial venous partial pressure of $\mathrm{CO}_{2}\left(\mathrm{PaCO}_{2}\right)>50 \mathrm{mmHg}$, and an initial venous $\mathrm{pH}>7.30 .{ }^{24}$ In another retrospective cohort study of children aged 0-18 years with respiratory distress on HFNC in the ED, Er et al..$^{28}$ have showed that while the unresponsive group had lower $\mathrm{SpO}_{2}, \mathrm{SpO}_{2} / \mathrm{FiO}_{2}$ ratio, and venous $\mathrm{pH}$, and higher $\mathrm{PaCO}_{2}$ on initiation, the diagnosis had no effect on the responsiveness to HFNC therapy. The authors suggested that patients receiving HFNC should be evaluated rapidly with blood gas and cardiorespiratory values. In this way, hypercarbia, respiratory acidosis, severe tachypnea and tachycardia can be determined early. That will enable us to identify patients who would not respond, and thus other treatment options would not be delayed.

\section{Use of HFNC in the Pediatric Emergency Department}

HFNC has recently become an indispensable treatment option for PED patients. ${ }^{7}$ It has been most commonly used for children with bronchiolitis which were included in almost all studies conducted in the ED. ${ }^{16-28}$ In all studies, in which HFNC therapy was compared with standard oxygen therapy, HFNC therapy was superior to standard oxygen in reducing the rate of intubation and PICU admission. ${ }^{17,23}$ In the largest one ever, Franklin et al. ${ }^{21}$ have found that the rate of treatment failure in infants receiving HFNC was $12 \%$ whereas in the standard-therapy group it was $23 \%$ (61\% of those responded to HFNC rescue therapy). They have also determined that no significant difference was detected in mortality, length of hospital stay or the duration of oxygen therapy. The findings of Kepreotes et al. ${ }^{19}$ study supported these results. In other prospective observational study comparing the effects of CPAP and HFNC in children with respiratory distress (age $=1$ 24 months) in the emergency operative unit, Vitaliti et al. ${ }^{27}$ have demonstrated that both CPAP and HFNC therapies were efficient in improving the clinical conditions of subjects with mild-to-moderate respiratory distress when compared with a control group, but clinical response in patients receiving CPAP was more favorable and rapid than in children treated with HFNC. In a retrospective cohort study, including 498 children younger than 2 years old receiving HFNC in the ED, in whom the most common final diagnosis was acute bronchiolitis
(46\%) followed by pneumonia (28\%) and asthma (8\%), Kelly et al. ${ }^{24}$ have reported that the intubation rate was lower in patients having acute bronchiolitis than in others. But, the evidences of Long et al. ${ }^{25}$ study have not supported this result. They have found that the failure rate was $43 \%$ and $35 \%$ in patients with acute bronchiolitis and pneumonia, respectively.

Another frequent reason for ED visits is acute asthma exacerbation which can require HFNC therapy. In studies involving children with acute asthma exacerbation in the ED, it has been shown that HFNC therapy had beneficial effects in these patients. ${ }^{23,25,28}$ In a prospective randomized pilot study including children aged 1-14 years presenting to ED with moderate-to-severe asthma exacerbations, Ballestero et al. ${ }^{29}$ compared HFNC with standard oxygen therapy and demonstrated that while HFNC was superior in reducing respiratory distress within the first 2 hours of treatment refractory to first line medication, it was not effective in decreasing the overall rates of PICU or ward admission. They also have reported that no side effects associated with HFNC use were observed.

HFNC may also support children having respiratory distress associated with other diseases, such as pneumonia, sepsis, croup, cardiac failure and apnoea, in the ED. ${ }^{23-25,27}$ In a recent retrospective cohort study, $\mathrm{Er}$ et al. ${ }^{28}$ evaluated 95 children aged 0-18 years with pneumonia receiving HFNC in the ED and found that the rate of therapy success was $81 \%$ in these patients. They also determined that HFNC provided improving significantly in the $R R, H R$, and respiratory score decreased at the first hour.

\section{Conclusion}

The majority of the studies on the use of HFNC in the PED were small observational studies and conducted in infants with bronchiolitis. The results of these studies have shown that HFNC was a feasible, safe and well-tolerated method for delivering oxygen and also reduced the rate of intubation and PICU admission.

However, there have been many points such as the initiation, the optimal flow rate, oral feeding and weaning that need to be clarified regarding this treatment. Although the initiation is controversial in older children, HFNC may be started with $6 \mathrm{~L} / \mathrm{min}$ flow rate and then increased up to $12 \mathrm{~L} / \mathrm{min}$ flow rate for children with bronchiolitis. $\mathrm{FiO}_{2}$ is adjusted at 0.4 initially and can be rised to 0.5-0.6 provided oxygen saturation is $>92 \%$. Enteral nutrition and breastfeeding should be continued in these children. The following weaning protocol can be recommended: $\mathrm{FiO}_{2}$ should be initially weaned to 0.4 before reducing flow rates by $0.5 \mathrm{~L} / \mathrm{min} / \mathrm{h}$ for neonates and $1 \mathrm{~L} / \mathrm{min} / \mathrm{h}$ for all other children providing the respiratory 
score remains under the initial trigger level. HFNC therapy is stopped when the flow rate reaches a value that is below than the initial with the oxygen saturations over $92 \%$ and a $\mathrm{FiO}_{2}$ of 0.4 or less.

Until further evidence is found, HFNC can be used as a respiratory support method in children. Despite beneficial effects of HFNC, still there is no comprehensive HFNC guideline and it has not been recommended by the international guidelines yet. Future researches are needed.

\section{Ethics}

Peer-review: External and Internal peer-reviewed.

Conflict of Interest: No conflict of interest was declared by the authors.

Financial Disclosure: The authors declared that this study received no financial support.

\section{References}

1. Meissner HC. Viral bronchiolitis in children. N Engl J Med. 2016;374:62-72.

2. Hasegawa K, Tsugawa Y, Brown DF, Mansbach JM, Camargo CA Jr. Temporal Trends in emergency department visits for bronchiolitis in the United States, 2006 to 2010. Pediatr Infect Dis J. 2014;33:11-8.

3. Nair H, Nokes DJ, Gessner BD, Dherani M, Madhi SA, et al. Global burden of acute lower respiratory infections due to respiratory syncytial virus in young children: a systematic review and metaanalysis. Lancet. 2010;375:1545-55

4. Ralston SL, Lieberthal AS, Meissner HC, Alverson BK, Baley JE, et al. Clinical Practice Guideline: The Diagnosis, Management, and Prevention of Bronchiolitis. Pediatrics. 2014;134:1474-502.

5. Frat JP, Coudroy R, Thille AW. Non-invasive ventilation or high-flow oxygen therapy: When to choose one over the other? Respirology. 2019;8:724-31.

6. Kalburgi S, Halley T, Kolaitis IN, Hood K, Mittal V. A Review of Heated High-Flow Nasal Cannula in Pediatrics From Critical Care to Ward Use. Curr Treat Options Peds. 2018;4:319-29.

7. Slain KN, Shein SL, Rotta AT. The use of high-flow nasal cannula in the pediatric emergency department. J Pediatr. 2017;93:36-45.

8. Mayfield S, Jauncey-Cooke J, Hough JL, Schibler A, Gibbons K, et al. High-flow nasal cannula therapy for respiratory support in children. Cochrane Database Syst Rev. 2014;3:CD009850.

9. Sinha IP, McBride AKS, Smith R, Fernandes RM. CPAP and high-flow nasal cannula oxygen in bronchiolitis. Chest. 2010;58:810-23.

10. Haq I, Gopalakaje S, Fenton AC, McKean MC, O'Brien CJ, et al. The evidence for high flow nasal cannula devices in infants. Pediatr Respir Rev. 2014;15:124-34.

11. Mikalsen IB, Davis P, Øymar K. High flow nasal cannula in children: a literature review. Scand J Trauma Resusc Emerg Med. 2016;93:112.

12. Chisti MJ, Salam MA, Smith JH, Ahmed T, Pietroni MA, et al. Bubble continuous positive airway pressure for children with severe pneumonia and hypoxaemia in Bangladesh: an open, randomised controlled trial. Lancet. 2015;386:1057-65.
13. Mace AO, Gibbons J, Schultz A, Knight G, Martin AC. Humidified high-flow nasal cannula oxygen for bronchiolitis: should we go with the flow? Arch Dis Child. 2018;103:303.

14. Shein SL, Slain KN, Rotta AT. High flow nasal cannula flow rates: New data worth the weight. J Pediatr. 2017;189:9-10.

15. Milési C, Pierre AF, Deho A, Pouyau R, Liet JM, et al. A multicenter randomized controlled trial of a $3-\mathrm{L} / \mathrm{kg} / \mathrm{min}$ versus $2-\mathrm{L} / \mathrm{kg} / \mathrm{min}$ high-flow nasal cannula flow rate in young infants with severe viral bronchiolitis (TRAMONTANE 2). Intensive Care Med. 2018;44:1870-8.

16. Arora B, Mahajan P, Zidan MA. Sethuraman U. Nasopharyngeal airway pressures in bronchiolitis patients treated with high-flow nasal cannula oxygen therapy. Pediatr Emerg Care. 2012;11:1179-84.

17. Mayfield S, Bogossian F, O'Malley L, Schibler A. High-flow nasal cannula oxygen therapy for infants with bronchiolitis: pilot study. J Paediatr Child Health. 2014;50:373-8.

18. Milani GP, Plebani AM, Arturi E, Brusa D, Esposito S, et al. Using a high-flow nasal cannula provided superior results to low-flow oxygen delivery in moderate to severe bronchiolitis. Acta Paediatr. 2016;105:e368-72.

19. Kepreotes E, Whitehead B, Attia J, Oldmeadow C, Collison A, et al. High-flow warm humidified oxygen versus standard low-flow nasal cannula oxygen for moderate bronchiolitis (HFWHO RCT): an open, phase 4, randomised controlled trial. Lancet. 2017;389:930-9.

20. Davison M, Watson M, Wockner L, Kinnear F. Paediatric high-flow nasal cannula therapy in children with bronchiolitis: A retrospective safety and efficacy study in a non-tertiary environment. Emerg Med Australas. 2017;29:198-203.

21. Franklin D, Babl FE, Schlapbach LJ, Oakley E, Craig S, et al. A randomized trial of high-flow oxygen therapy in infants with bronchiolitis. N Engl J Med. 2018;378:1121-31.

22. Yurtseven A, Turan C, Erseven E, Saz EU. Comparison of heated humidified high-flow nasal cannula flow rates (1-L. $\mathrm{kg} \cdot \mathrm{min}$ vs 2-L.kg.min ) in the management of acute bronchiolitis. Pediatr Pulmonol. 2019;6:1-7.

23. Wing R, James C, Maranda LS, Armsby CC. Use of high-flow nasal cannula support in the emergency department reduces the need for intubation in pediatric acute respiratory insufficiency. Pediatr Emerg Care. 2012;28:1117-23.

24. Kelly GS, Simon HK, Sturm JJ. High-flow nasal cannula use in children with respiratory distress in the emergency department: predicting the need for subsequent intubation. Pediatr Emerg Care. 2013;29:888-92.

25. Long $E$, Babl FE, Duke T. Is there a role for humidified heated highflow nasal cannula therapy in paediatric emergency departments? Emerg Med J. 2016;33:386-9.

26. Söğütlü $Y$, Biçer $S$, Kurt $G$, Şah $O$, Namdar $M$, et al. Outcomes of High-flow Nasal Cannula Oxygen Therapy on the Vital Signs of Children with Lower Respiratory Tract Diseases. J Pediatr Emerg Intensive Care Med. 2016;3:121-30.

27. Vitaliti G, Vitaliti MC, Finocchiaro MC, Di Stefano VA, Pavone $P$, et al. Randomized Comparison of Helmet CPAP Versus High-Flow Nasal Cannula Oxygen in Pediatric Respiratory Distress. Respir Care. 2017;62:1036-42.

28. Er A, Çağlar A, Akgül F, Ulusoy E, Çitlenbik H, et al. Early predictors of unresponsiveness to high-flow nasal cannula therapy in a pediatric emergency department. Pediatric Pulmonol. 2018;53:809-15.

29. Ballestero Y, De Pedro J, Portillo N, Martinez-Mugica O, Arana-Arri E, et al. Pilot Clinical Trial of High-Flow Oxygen Therapy in Children with Asthma in the Emergency Service. J Pediatr. 2018;194:204-10. 
30. Spentzas T, Minarik M, Patters AB, Vinson B, Stidham G. Children with respiratory distress treated with high-flow nasal cannula. J Intensive Care Med. 2009;24:323-8.

31. Riese J, Fierce J, Riese A, Alverson BK. Effect of a Hospital-wide High-Flow Nasal Cannula Protocol on Clinical Outcomes and Resource Utilization of Bronchiolitis Patients Admitted to the PICU. Hosp Pediatr. 2015;5:613-8.

32. Wang J, Lee KP, Chong SL, Loi M, Lee JH. High flow nasal cannula in the emergency department: indications, safety and effectiveness. Expert Rev Med Devices. 2018;14:1-7.

33. Dysart K, Miller TL, Wolfson MR, Shaffer TH. Research in high flow therapy: mechanisms of action. Respir Med. 2009;103:1400-5.

34. Numa AH, Newth CJ. Anatomic dead space in infants and children. J Appl Physiol. 1996;80:1485-9.

35. Van Hove SC, Storey J, Adams C, Dey K, Geoghegan PH, et al. An Experimental and Numerical Investigation of $\mathrm{CO}_{2}$ Distribution in the Upper Airways During Nasal High Flow Therapy. Ann Biomed Eng. 2016;44:3007-19.

36. Frizzola M, Miller TL, Rodriguez ME, Zhu Y, Rojas J, et al. High-flow nasal cannula: impact on oxygenation and ventilation in an acute lung injury model. Pediatr Pulmonol. 2011;46:67-74.

37. Shepard JW Jr, Burger CD. Nasal and oral flow-volume loops in normal subjects and patients with obstructive sleep apnea. Am Rev Respir Dis. 1990;142:1288-93.

38. Pham TM, O'Malley L, Mayfield S, Martin S, Schibler A. The effect of high flow nasal cannula therapy on the work of breathing in infants with bronchiolitis. Pediatr Pulmonol. 2014;50:713-20.

39. Chidekel A, Zhu Y, Wang J, Mosko JJ, Rodriguez E, et al. The effects of gas humidification with high-flow nasal cannula on cultured human airway epithelial cells. Pulm Med. 2012;2012:380686.

40. Milesi C, Baleine J, Matecki S, Durand S, Combes C, et al. Is treatment with a high flow nasal cannula effective in acute viral bronchiolitis? A physiologic study. Intensive Care Med. 2013;39:1088-94.

41. Spentzas T, Minarik M, Patters AB, Vinson B, Stidham G. Children with respiratory distress treated with high-flow nasal cannula. J Intensive Care Med. 2009;24:323-8.

42. Hutchings FA, Hilliard TN, Davis PJ. Heated humidified high-flow nasal cannula therapy in children. Arch Dis Child. 2015;100:571-5.

43. Betters KA, Hebbar KB, McCracken C, Heitz D, Sparacino S, et al. A Novel Weaning Protocol for High-Flow Nasal Cannula in the PICU. Pediatr Crit Care Med. 2017;18:e274-80.

44. Sochet AA, McGee JA, October TW. Oral Nutrition in Children With Bronchiolitis on High-Flow Nasal Cannula Is Well Tolerated. Hosp Pediatr. 2017;7:249-55
45. Slain KN, Martinez-Schlurmann N, Shein SL, Stormorken A. Nutrition and High-Flow Nasal Cannula Respiratory Support in Children With Bronchiolitis. Hosp Pediatr. 2017;7:256-62.

46. Bressan S, Balzani M, Krauss B, Pettenazzo A, Zanconato S, et al. High-flow nasal cannula oxygen for bronchiolitis in a pediatric ward: a pilot study. Eur J Pediatr. 2013;172:1649-56.

47. Testa G, lodice F, Ricci Z, Vitale V, De Razza F, et al. Comparative evaluation of high-flow nasal cannula and conventional oxygen therapy in paediatric cardiac surgical patients: a randomized controlled trial. Interact Cardiovasc Thorac Surg. 2014;19:456-61.

48. McKiernan C, Chua LC, Visintainer PF, Allen H. High flow nasal cannulae therapy in infants with bronchiolitis. J Pediatr. 2010;156:634-8

49. Schlapbach LJ, Straney L, Gelbart B, Alexander J, Franklin D, et al. Burden of disease and change in practice in critically ill infants with bronchiolitis. Eur Respir J. 2017;49:1-11.

50. Schibler A, Pham TM, Dunster KR, Foster K, Barlow A, et al. Reduced intubation rates for infants after introduction of high-flow nasal prong oxygen delivery. Intensive Care Med. 2011;37:847-52.

51. Hegde S, Prodhan P. Serious air leak syndrome complicating high-flow nasal cannula therapy: a report of 3 cases. Pediatrics. 2013;131:e939-44.

52. ten Brink F, Duke T, Evans J. High-flow nasal prong oxygen therapy or nasopharyngeal continuous positive airway pressure for children with moderateto-severe respiratory distress?*. Pediatr Crit Care Med. 2013;14:e326-31.

53. Jhung MA, Sunenshine RH, Noble-Wang J, Coffin SE, St John K, et al. A national outbreak of Ralstonia mannitolilytica associated with use of a contaminated oxygen-delivery device among pediatric patients. Pediatrics. 2007;119:1061-8.

54. Collins CL, Barfield C, Horne RS, Davis PG. A comparison of nasal trauma in preterm infants extubated to either heated humidified high-flow nasal cannulae or nasal continuous positive airway pressure. Eur J Pediatr. 2014;173:181-6.

55. Abboud PA, Roth PJ, Skiles CL, Stolfi A, Rowin ME. Predictors of failure in infants with viral bronchiolitis treated with high-flow, highhumidity nasal cannula therapy*. Pediatr Crit Care Med. 2012;13:e343-9.

56. Wraight TI, Ganu SS. High-flow nasal cannula use in a paediatric intensive care unit over 3 years. Crit Care Resusc. 2015;17:197201. 